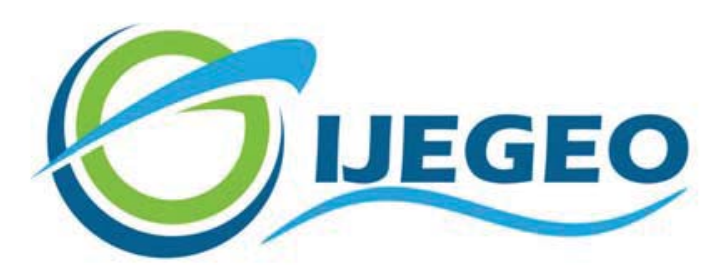

International Journal of Environment and Geoinformatics (IJEGEO) is an international, multidisciplinary, peer reviewed, open access journal.

\title{
Tsunami Hazard Assessment and Potential Risk Mitigation Requirement for Sea of Marmara Coastline
}

\section{Ayhan SALAR, Cem GAZIOĞLU}

\author{
Chief in Editor \\ Prof. Dr. Cem Gazioğlu \\ Co-Editors \\ Prof. Dr. Dursun Zafer Şeker, Prof. Dr. Şinasi Kaya, \\ Prof. Dr. Ayşegül Tanık and Assist. Prof. Dr. Volkan Demir
}

Editorial Committee (September 2021)

Assoc. Prof. Dr. Abdullah Aksu (TR), Assit. Prof. Dr. Uğur Algancı (TR), Prof. Dr. Bedri Alpar (TR), Assoc. Prof. Dr. Aslı Aslan (US), Prof. Dr. Levent Bat (TR), Prof. Dr. Paul Bates (UK), İrşad Bayırhan (TR), Prof. Dr. Bülent Bayram (TR), Prof. Dr. Luis M. Botana (ES), Prof. Dr. Nuray Çağlar (TR), Prof. Dr. Sukanta Dash (IN), Dr. Soofia T. Elias (UK), Prof. Dr. A. Evren Erginal (TR), Assoc. Prof. Dr. Cüneyt Erenoğlu (TR), Dr. Dieter Fritsch (DE), Prof. Dr. Çiğdem Göksel (TR), Prof.Dr. Lena Halounova (CZ), Prof. Dr. Manik Kalubarme (IN), Dr. Hakan Kaya (TR), Assist. Prof. Dr. Serkan Kükrer (TR), Assoc. Prof. Dr. Maged Marghany (MY), Prof. Dr. Michael Meadows (ZA), Prof. Dr. Nebiye Musaoğlu (TR), Prof. Dr. Masafumi Nakagawa (JP), Prof. Dr. Hasan Özdemir (TR), Prof. Dr. Chryssy Potsiou (GR), Prof. Dr. Erol Sarı (TR), Prof. Dr. Maria Paradiso (IT), Prof. Dr. Petros Patias (GR), Prof. Dr. Elif Sertel (TR), Prof. Dr. Nüket Sivri (TR), Prof. Dr. Füsun Balık Şanlı (TR), Prof. Dr. Uğur Şanlı (TR), Duygu Ülker (TR), Prof. Dr. Seyfettin Taş (TR), Assoc. Prof. Dr. Ömer Suat Taşkın (TR), Assist. Prof. Dr. Tuba Ünsal (TR), Dr. Manousos Valyrakis (UK), Dr. İnese Varna (LV), Dr. Petra Visser (NL), Prof. Dr. Selma Ünlü (TR), Assoc. Prof. Dr. Oral Yağcı (TR), Prof. Dr. Murat Yakar (TR), Assoc. Prof. Dr. İ. Noyan Yılmaz (AU); Assit. Prof. Dr. Sibel Zeki (TR)

Abstracting and Indexing: TR DIZIN, DOAJ, Index Copernicus, OAJI, Scientific Indexing Services, International Scientific Indexing, Journal Factor, Google Scholar, Ulrich's Periodicals Directory, WorldCat, DRJI, ResearchBib, SOBIAD 
Review Article

\title{
Tsunami Hazard Assessment and Potential Risk Mitigation Requirement for Sea of Marmara Coastline
}

\author{
Ayhan Salar ${ }^{\text {(iD) }}$, Cem Gazioğlü ${ }^{1,2, *(i)}$ \\ ${ }^{1}$ Istanbul University, Institute of Marine Sciences and Management, Department of Marine Environment, 34134 Vefa Fatih Istanbul/TR \\ ${ }^{2}$ Istanbul University, Faculty of Architecture, Department of Architecture 34126 Beyazit, Fatih Istanbul/TR
}

*E-mail: cemga@istanbul.edu.tr

Received 01 June 2020

Accepted 05 Apr 2021

How to cite: Salar and Gazioğlu (2021). Tsunami Hazard Assessment and Potential Risk Mitigation Requirement for Sea of Marmara Coastline, International Journal of Environment and Geoinformatics (IJEGEO), 8(3):359-368. doi. 10.30897/ijegeo.908180

\begin{abstract}
The westward movement of the seismic energy along the North Anatolian Fault (NAF) during the 20th century has increased the probability that the next activity will be offshore in the Sea of Marmara. According to historical records 35 tsunami events have impacted the Sea of Marmara coasts (Altınok, et al., 2011). Offshore seismic sources may trigger these tsunamis directly or through coseismic underwater failure. The 1999 İzmit Bay tsunami led to more comprehensive analyses of these events which are generally caused by underwater failures close to the target coastline. Waves so generated can arrive at nearby coastlines in minutes, causing extensive damage and loss of life. Here this paper proposes, on the basis of tsunami models in the Sea of Marmara and methodology used internationally, tsunami inundation maps for the areas along the Sea of Marmara coasts in the light of both remote sensing and DTMs data. This investigation highlights the information regarding the most vulnerable tsunamigenic areas. Such maps for selected areas help to understand the possible effects on those regions and should only be used for evacuation planning and reducing possible hazard
\end{abstract}

Keywords: Sea of Marmara, Tsunami, Hazard Assessment,

\section{Introduction}

Tsunami (or tidal wave) is well-known because the natural phenomena comprising of a series of waves is produced as soon as the waves have swiftly lead on a massive scale. Tsunami is a Japanese word which means, of the harbor ("tsu") and wave ("nami"). Tsunamis are fairly common in Japan (or Asia) and in recent centuries, thousands of Japanese have been killed by Tsunami waves. Tsunamis are one of the most dreadful natural disasters; they could cause abysmal damage to all kind of lives in the hinterland within instantly. Earthquakes, landslides, volcanic eruptions, sub-bottom slumps and even meteor impacts can disturb bodies of water so as to form tsunamis, which are also known as a tidal waves. Tsunamis can have heights of $<30 \mathrm{~m}$ and reach speed of $<950$ kilometers per hour. They are described by long wavelengths of $<200$ kilometers and long periods. A tsunami can propagate in any direction and thus, dependent on the location of the source, path of propagation and near shore morphology form a risk to any vulnerable coastline.

This tsunami is a synonym for seismic sea wave. In this context, a tsunami is a seismic sea wave containing tremendous amounts of energy as a result of its mode of formation, i.e., the factor that causes a seismic wave. It could be a submarine landslide, a shifting of rocks triggered by an earthquake or volcanic explosion. Further, tsunamis are flat waves with long periods and long wavelengths; they grow in height in shallow water and flood the shoreline, sometimes causing catastrophic destruction. Consequently, tsunamis are temporary oscillations of sea level with periods longer than the wind waves and shorter than tides of the tsunami, and shorter than a few days of storm surge.

The near shore seabed morphology determines both the wave path towards shore as well as the wave run-up characteristics (Figure 1) (Alpar, et al., 2002). Inundations of waves are studied by several investigations. Especially since the Indian Ocean tsunami in 2004, it is confirmed that the major effect of inundations is material which covered coastal zones. Investigations have been applied to define and identify the impact of tsunamis on coastal environments such as the inundation, run up, deposition, vegetation, settlements, population, etc. in coastal zone which under tsunamigenic risks. The tsunamigenic damages were significantly reduced in places behind relatively wide, densely grown vegetation belts compared with the damage in places having no vegetation (Kumar, et al, 2008; Nandasena, et al., 2008).

\section{Sea of Marmara}

Sea of Marmara (SoM) coasts have been frequently struck by tsunamis. A number of large destructive earthquakes and tsunamis have happened from ancient times to the present in coastal areas of peninsula of Anatolia. As Anatolian Block is surrounded by several seas where active tectonics occurs, numerous tsunamis 
have caused damages to Anatolian coasts (Kuran and Yalçıner, 1993; Altinok and Ersoy, 2000; Yalçıner et al., 2002). The SoM coasts have been frequently struck by tsunamis with respect to other coastal areas of the Aegean, Mediterranean and Black. Main sources are earthquakes and co-seismic slope failures source harmful tsunamis in shoreline and coastal zone, depending on their morphological features, bathymetry and distance from source.

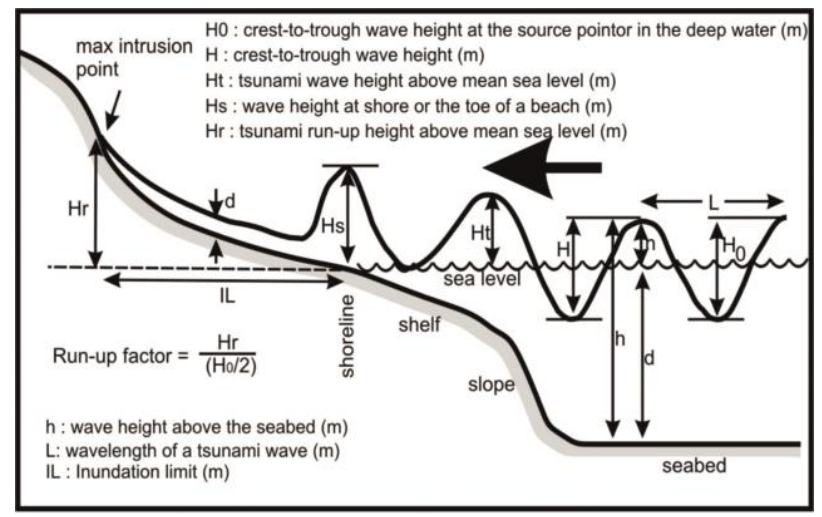

Fig. 1. Graph explains terms used to express the wave height of a tsunami (modified from Alpar et al., 2002

The SoM is an $11110 \mathrm{~km}^{2}$ inland sea in northwest Anatolia located between the Black Sea and Aegean Sea. It has very complex and unique sub-bottom morphology (Figure 2). The main characteristic of SoM is the eastwest directed Marmara Trough, which consists of Çınarcık, Central, Silivri, and Tekirdag basins separated by two ridges (Gazioğlu, et al., 2002). This very complicated sub-bottom morphology of the Marmara Trough exists along the route of the northern segment of the North Anatolian Fault Zone (NAFZ) (Figure 2), which has been extensively identified since Pinar (1942) recognized the existence of a major fault along the SoM in 1942. NAFZ is the one of the active fault zones of world.

The NAFZ is a major continental strike slip fault that is taking up the dextral motion between the Anatolian and Black Sea blocks as a result of the impact between the Arabian and Eurasian plates and the westward extrusion of the Anatolian block (Barka and Kadinsky-Cade, 1988; McClusky et al., 2000). Over a distance greater than 1 $000 \mathrm{~km}$, it associates the eastern Turkey in the east to the Gulf of Corinth (Greece) in the west. The fault has produced a series of 11 large earthquakes (Ms>6.7) during the 20th century and has ruptured most of its length during a striking westward propagating sequence between 1939 and 1999 (Barka, 1996; Stein et al., 1997; Ambraseys and Jackson, 2000; Reilinger et al., 2000).

Available focal mechanisms all display a dextral strike slip faulting in agreement with the analysis of surface ruptures (Barka and Kadinsky-Cade, 1988).

Pinar (1942) proposed that an E-W trending major fault existed in the SoM, extending from the Gulf of Izmit to the Ganos Mountain System. Since P1nar (1942), numerous studies have been carried out to investigate the active tectonics of the SoM. Pfannensteil (1944) proposed that the basins and ridges in the Marmara Trough were formed by normal faulting. Ketin (1948) identified the NAFZ along northern Anatolia as a rightlateral strike-slip fault.

Many geoscientist offered different tectonic models to explain the geological evolution of the NAFZ in the SoM. Some geoscientist suggested that the northern branch of the NAFZ extended into the SoM as a single shear zone (Pınar 1942;Şengör 1979; Şengör et al. 1985), whereas others advocated that the area of the SoM was cut by an EW-trending graben (Ketin 1968; Crampin and Evans 1986; Smith et al. 1995). The NAFZ in this area has also been considered to represent a combination of en-echelon strike-slip faults and pull-apart basins (Barka and Kadinsky-Cade 1988; Barka 1992; Wong et al. 1995; Ergün and Özel 1995; Armijo et al. 1999).

The bathymetric data have demonstrated clearly that along the extension of the NAFZ there is continuous lineament stretching ENE-WSW from the Ganos Mountain System in the west to Büyükçekmece Lagoon in the east. Latest geoscientific investigations with the distributions of the epicenters of earthquake reveal that the active tectonic of the SoM is mainly controlled by North Anatolian Fault (NAF) (Gürbüz et al., 2000; İmren et al., 2001; Gazioğlu et al., 2002; 2012; 2014; 2017; Gökaşan et al., 2003; Şengör et al., 2005). The northern and southern boundaries of the sub-basins of the Marmara deep basin, demonstrate little seismic activities compared to the NAFZ. Latest studies also display that the NAFZ cuts and offsets the other faults and is thus younger (İmren et al., 2001; Gökaşan et al., 2001-2003; Le Pichon et al., 2001; Gazioğlu et al., 2002; Rangin et al., 2004; Şengör et al., 2005; Ustaömer et al., 2008; Y1lmaz, et al., 2009). A number of large destructive tsunamis and earthquakes have happened from ancient times to the present in coastal areas of peninsula of Anatolia, SoM and Istanbul. Historical records show geoscientists to SoM and Istanbul costs have had many tsunami events. The westward propagation of the seismic ruptures along the NAFZ during the 20th century has increased the probability that the next rupture will be located offshore, in the SoM, in the prolongation of the 1999 Izmit earthquake faulting. SoM is one of the most seismically active seas of the world in the light of the recently geoscientific studies. The generative mechanism of the tsunami waves are related both seismic activities and mass movements in SoM. According to documentations of historical tsunamis, 35 tsunamis have impacted the SoM shorelines (Altınok et al., 2011). Historical tsunamis have been evidenced in the SoM e.g., those associated with the 1509 and May 1766 strong earthquakes that broke submarine parts of the NAFZ, in the vicinity of Istanbul, and future submarine events are expected to produce tsunamis as well that could be triggered either by submarine coseismic displacements, slumps or by landsliding (Gazioğlu et al., 2005; Hébert, et al., 2005). Submarine landslides were considered as another important factor affecting the sub-bottom morphology of the SoM (Gökaşan et al., 2003; Gazioğlu et al., 2005). The extensive period between events in a detailed position makes the problem more complicated. 


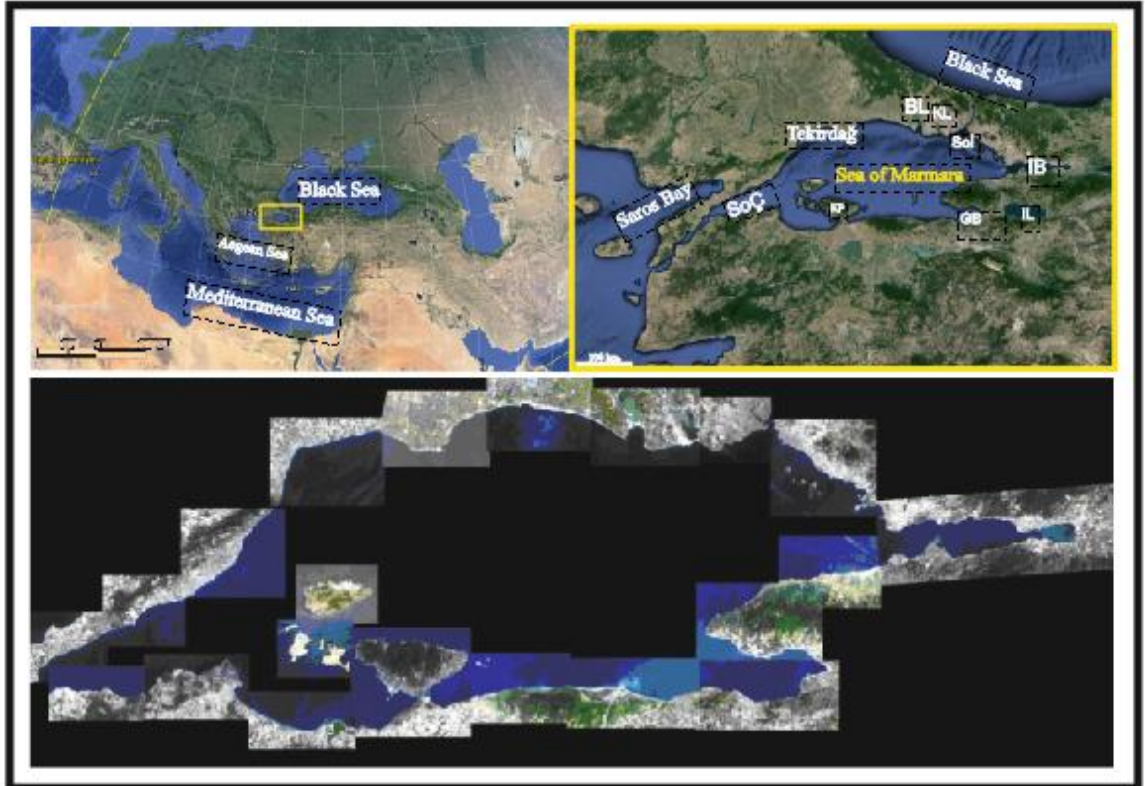

Fig. 2. a. Location of SoM. b. Soİ: Strait of İstanbul (Bosphorus), SoÇ: Strait of Çanakkale (Dardanelles), İB: İzmit Bay, GB: Gemlik Bay, KP: Kapıdağ Peninsula, BL: Büyükçekmece Lake, KL: Küçükçekmece Lake. c. Satellite data of Study area (Abalı, 2005).

SoM coastline is subjected to a near-field hazard - a tsunami generated in something under 2 hours tsunami travel time to the locality. Different from far-field tsunamis, it may be difficult to generalise the effects of near-field tsunamis, because there is a large variability over short distances of the height of tsunamis and their destructiveness. Coseismic underwater failures accompanying earthquakes on the NAF (Figure 2) in the SoM (Alpar et al., 2001), which shape and move vast quantities of sediment down on the continental slopes, are mostly responsible for the generation of these tsunamis (Alpar et al., 2001; Yalçıner et al., 2002). Özeren, et al. (2010) approach potential The sediment movement is transmitted to the overlying sea surface, forming the first tsunami wave which propagates rapidly. Since underwater failures on the continental slopes are close to shore, the generated waves arrive to the target shoreline in a short time with a low dispersion and cause great run-up (Synolakis et. al., 2002).

Hoping it limits construction of new essential facilities and special occupancy structures in tsunami flooding zones for public safety, we attempt to assess tsunami hazard focused along the SoM coasts. It may be important for particular areas where the inland distance of inundation is greater.

\section{Tsunamis observed in SoM}

According to current investigations catastrophic tsunamis affected SoM coasts 35 times (Altınok, et al., 2011). The paucity of direct records or accounts makes, however, a rigorous estimation of the run-up values rather difficult, and the analysis of available documents remains somehow controversial (Hébert et al., 2005). Even the historical records of near-field tsunamis is often incomplete due to low quality and lack of data, especially in the case of older events, there are many events well documented in several studies (e.g. Çesmizade, 1766-1768; Eginitis, 1894; Sadi, 1912; Mihailovic, 1927; Orgun, 1941; Heck, 1947; Ambraseys, 1960; Antonopoulos, 1978; Soysal et al., 1981; Papadopoulos and Chalkis, 1984; Soysal, 1985; Papazachos et al., 1986; Ambraseys and Finkel, 1991, 1995; Öztin and Bayülke, 1991; Batur, 1994, 1999; Guidoboni et al., 1994; Selimoglu, 1999; Papadopoulos, 2000; Altınok et al, 2003). During last 1600 years, at least 21 historic tsunamis are known to be felt in İstanbul, nearly half of them impacted its coasts. The size and effects of the tsunami waves in the SoM are straightly related to their positions and size of the source mechanisms. One of the early records are: In 120/128? the earthquake which affected the SE Marmara Region and its tsunamis attack to Kapıdağ Peninsula (Guidoboni et al., 1994).

In 24.08.358, Tsunami observed in Izmit after massive earthquake in the SoM (Guidoboni et al., 1994; Ambraseys and Finkel, 1991). In 24-26.09.477/480? Tsunami waves destroyed coastline of Istanbul after earthquake which affect large part of southern part of Marmara Region (Guidoboni et al., 1994; Ambraseys and Finkel, 1991).

On the basis of historical records, the most destructive tsunamis are the 10.09.1509, 10.07.1894 and 09.08.1912. The most catastrophic tsunami for region is happened in 1509. In 1509, the magnitude of this Istanbul earthquake was close to 8.0. The tsunami wave height was most probably more than $6 \mathrm{~m}$ above mean sea level along the Istanbul coasts. Sea inundated the area behind the city walls of Istanbul. The locality of this observation is difficult to specify precisely because the city towers extend more than $7 \mathrm{~km}$ along the coast. In 1894, the tsunami induced by the earthquake was effective in 
Istanbul when the sea receded up to $50 \mathrm{~m}$ and then returned. The residence of the sea and consequently sea water inundation to its original level was also confirmed around the Prince Islands and on the northern coast from southern coastline of Istanbul (Büyükçekmece to Kartal). There was no permanent change to the coastline. The sea rose up and inundated $200 \mathrm{~m}$. The tsunami wave height was less than $6 \mathrm{~m}$ and the earthquake magnitude was less than 7.0. The Karaköy and Azapkapı Bridges crossing the estuary Golden Horn were under the water. Approximately 10 minutes before the earthquake, the sea receded at Yeşilköy and not long after, huge waves attacked the coast and inundated up to the 3 rows of houses and even swept off the first row. $\left(41^{\circ} 00\right.$ ' $\mathrm{N}$ $29^{\circ} 00^{\prime} \mathrm{E}$ ). $\mathrm{M}=6.6$, Tsunami intensity is 3 , which is defined by Ambraseys (1962) In 1912, an earthquake occurred on the Ganos fault segment, at western end of the North Anatolian fault in the SoM. An underwater failure observed on the multibeam bathymetry is associated with this earthquake.

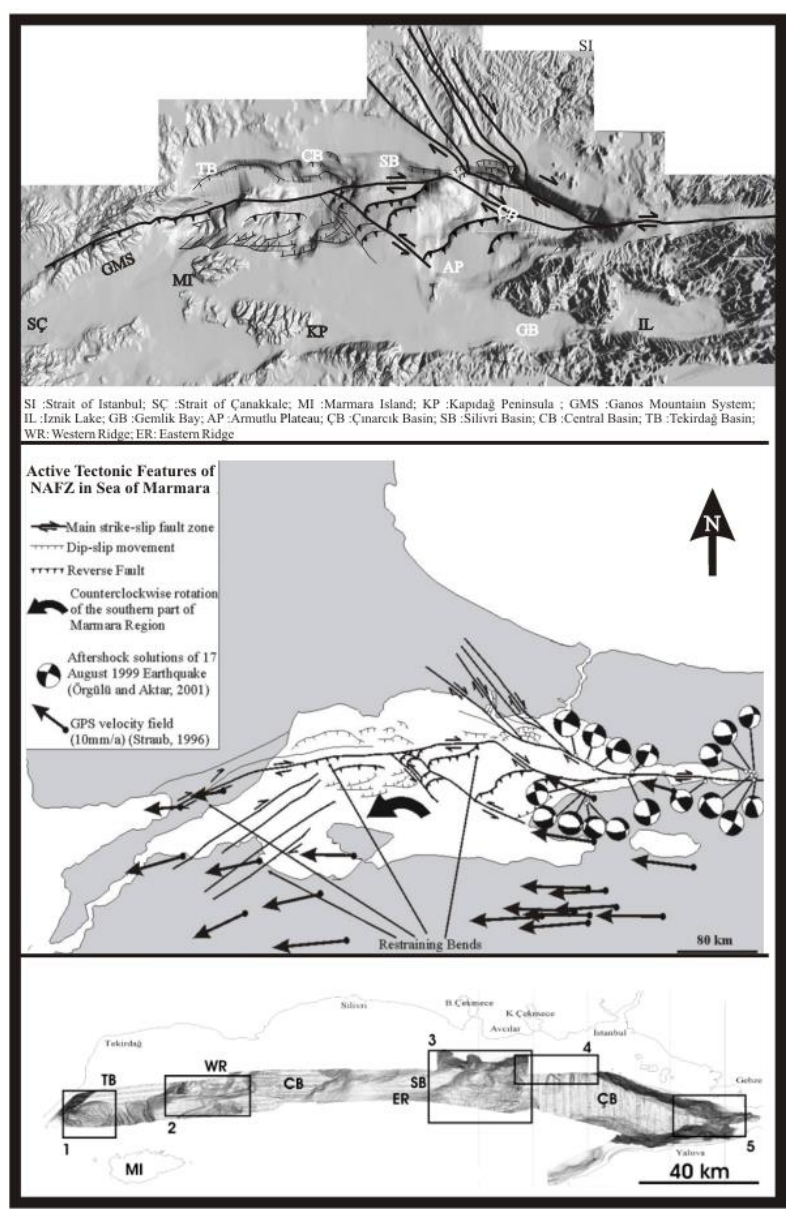

Fig. 2 a. Faults map of SoM from multi-beam bathymetric and seismic data, b. Correlation faults, earthquake solutions (Örgülü and Aktar, 2001), and GPS velocity fields (Straub, 1996) of Marmara Region c. Images taken from the area between the northern slope and the northern shelf with multibeam echo sounding show materials probably carried by submarine landslides (modified from Yaltırak, 2002; Gökaşan et al., 2002; Gökaşan et al., 2003; Gazioğlu et al., 2005).

Recent studies by Altınok et al. (2003) contributed many new findings to this tsunami. Related waves were observed along the Istanbul coasts an in the Strait of
Istanbul. At Yeşilköy, the sea lifted a rowing-boat up to a height of $2.7 \mathrm{~m}$. During this event, the sea receded about 10 minutes before the earthquake and huge waves caused by the earthquake swept off the first row of houses ashore in Yeşilköy. Similar observations are valid along the coastline from Kartal to Büyükçekmece. The waves inundated into the Golden Horn and flooded the Karaköy (4.0 m) and Azapkap1 (4.5 m) bridges. In 1999, $\mathrm{Mw}=7.4$ earthquake struck İzmit Bay.

Co-seismic subsidence is a matter of fact along the southern coasts of the bay. Even the accompanying small amplitude $(2.6 \mathrm{~m})$ tsunami waves was only effective in the central part of İzmit Bay (Imamura et al., 1999; Yalçıner et al., 2001a; Altınok et al., 2001b), irregular activities were observed around the Prince islands and in the Strait of Istanbul. The sea receded at the Heybeliada dock. After the earthquake, the walls of a Navy School located at the midway of the strait and separated from coast by $10-\mathrm{m}$ wide asphalt road, were poured with splashed sea water about $2 \mathrm{~m}$ above the sea level (Altınok et al., 2003). The advent and technological development of computers in the last decade has dramatically improved the quality of scientific research, allowing the possibility for numerical simulations of unprecedented dynamical range and sophistication of physical modelling. Numerical simulations are useful tools for analysing tsunami propagation and coastal amplification. This means that the whole range of spatial and temporal scales of the tsunamis must be resolved. The tsunami waves generated by earthquakes depend on the size and the impact of the source mechanism on the displaced water. On the other hand, those generated by underwater landslides are governed by the landslide geometry and its kinematics (Grilli and Watts, 1999).

A possible future earthquake occurring in the SoM has a tsunamigenic potential and may set in motion submarine landslides (or slumps) with additional tsunamigenic sources. Features of old mass movements have been identified by several studies in SoM (Altinok et al., 1999, Alpar and Yaltirak, 2002; Yüksel et al., 2002 and Gazioğlu et al., 2005) and scenarios of tsunamis induced by earthquake-triggered underwater slides have been analysed by Yalçiner et al., 2002.

By estimating different underwater landslide and earthquake scenarios in the SoM, Yalçıner et al (2001b), Yalçıner et al., (2002), Hébert, et al., (2005), Hayır et al., (2008) and Kılınç et al. (2009) have modelled tsunamis. According Yalçıner et al (2001b) and Yalçıner et al (2002) tsunami simulation model considers a two-layer flow which makes this computation tool to be more realistic. The layers are the water column and the moving mass at the sea bottom. This model, known as two-layer, solves the nonlinear wave equations at the same time by using the finite difference technique and following the leap-frog solution procedure within two interfacing layers with suitable kinematic and dynamic boundary conditions at the sea bed, interface and water surface (Imamura and Imteaz, 1995; Özbay, 2000). Yalçıner et al. (2002) proposed 3 different hypothetical 
tsunami scenarios; an underwater failure at offshore Yenikap1, another one offshore Tuzla, and an earthquake on the Armutlu Fault and two accompanying landslides located along this fault (Figure 3). These scenarios showed that the tsunami waves can reach the nearest coastal area within 5-10 minutes (see Figs. 7-10 in Yalçıner, et.al., 2002). The numerically simulated run-up elevations showed that the maximum positive tsunami amplitudes near the shore can exceed the 3-m level on some parts of the coast, even reaching the 5-m level at some localities (Figure 3) depending on the source and the coastal topography. Temporal histories, i.e. sequence and relative height of tsunami waves, showed similar appearances.

These numerical models predicted lesser tsunami runups in some areas; however, one should not underestimate possible flooding which may occur from subsidence. Therefore, all these effects should be considered as important risks for the shores of the SoM where the coastline is densely populated and widely used for many purposes.

Precisely inundation and run up mapping is exactly difficult both using conventional methods. Remote sensing technologies are one of the most economically method for investigation large areas which are tsunamigenic vulnerable. Inundation maps are demonstrations of coastal areas that identify regions, populations that are under tsunamigenic risks. Inundation maps require an assessment of geological hazards and the coastal flooding calculation, which could be used by authorities (Kumar et al., 2008). Tsunami inundation patterns are governed by the shelf, nearshore and beach bathymetries, as well as wave shapes, directions, angles and frequencies. Impact of the tsunami waves controlled by near shore seafloor topography, elevation of coastal landforms and morphological features of coastal zone. Assessing detailed tsunami hazards at any particular requires a full ocean tsunami model initiated by an appropriate source, coupled to a nearshore tsunami model using detailed local bathymetry. In this investigation, adopts a different geomorphology and land use on tsunami run-up and penetration.

The inundation map was produced by numerically simulating the resulting tsunami waves due to scenario underwater failures, and mapping the maximum inland flooding limit. The first part was done by computer methods. The last step was accomplished chiefly by prior conclusions about inland penetration depending on the circumstantial characteristics of the inundation area and available topographic data (Priest, 1995).

Tsunami flooding or the volume of water carried onshore is directly related with the size of tsunami and its wave period. On the other hand, the cross-sectional area of coastline flooded by a tsunami is almost equal to that of water under the tsunami wave crest close to shore (Hills and Mader, 1997). The limit of landward incursion is the maximum distance that run-up can penetrate inland and can be given the following formula;

$$
\mathrm{x}_{\max }=(\mathrm{Hs}) 1.33 \mathrm{n}-2 \mathrm{k}
$$

where $\mathrm{k}$ is a constant and taken as 0.06 for many tsunamis. The term $\mathrm{n}$ is another constant and depends on the characteristics of the inundation area. It is 0.015 for flat topography, 0.03 for settlement and 0.07 for forest (Figure 4)

Dry-land inundation distance across relatively flat ground was inferred by extrapolating the run-up elevation at the shoreline inland until a barrier was encountered or until a lateral distance was reached that conforms approximately to the above equation.

On the basis of this graph, a tsunami $2.6 \mathrm{~m}$ high can penetrate $950 \mathrm{~m}$ inland for smooth plains. However, since the study area is a developed land on flat coastal plains, such a tsunami can only penetrate about $250 \mathrm{~m}$ inland.

One of the latest sources of error is uncertainty in the absolute run-up elevation at the open coast. Due to the inherent uncertainties in tsunami models, the parameters we used in calculations (models, topography etc) and our judgement to infer inundation, the resulting error is difficult to quantify. Vertical precision, for example, depended on the spacing of the elevation contours and the proximity of the contours to the inferred run-up elevation. The maximum uncertainty between contours is $100 \%$ of the contour interval. Where the inundation distance fell by chance at or very close to an elevation contour, the precision is better. In addition, the precision may be large at inlets, lagoons, river mouths and estuaries and smaller at steep shorelines.

Considering the general characteristics of the earthquake characteristics of the past, it should be considered that the time of the wave to reach the northern coasts (between Silivri and Marmara Ereğlisi) may be approximately 5 minutes and the time to reach the southern coasts may be approximately 12 minutes. In this context, early warning systems should be developed for the SoM coasts. The climbing heights of the wave on the coasts are $10 \mathrm{~km}$ on the northern coast and will exceed approximately $3 \mathrm{~m}$ on the coastline longer than $2.5 \mathrm{~m}$ in the South coasts of SoM. Taking into consideration the simulated tsunami waves due to scenario underwater failures, topographic elevations, settlement conditions and geographic characteristics of the inundation area, the maximum inland flooding limits were developed for the maximum wave heights at shore. The inundation distance was calculated on the basis of circumstantial characteristics of the inundation area along the coastal zone which was classified for smooth terrains and areas covered in buildings. There are no any landscapes densely covered with forest. Occasional coastal terrain at some localities limits inundation. These maps may be useful to restrict construction of certain types of essential facilities and special occupancy structures within the tsunami inundation zone. These lines are subject to changes on the basis of prehistoric tsunami deposits found along the coast, further computer tsunami modelling, and scientific studies of other tsunamis that occurred in the SoM. 
In normal conditions, sea level changes should be considered and possible coseismic subsidence should be added to results of inundation limit as an additional runup. Even the tidal amplitudes are small in the SoM with a mean spring range of $3-5 \mathrm{~cm}$, seasonal sea level changes are in the order of $10-20 \mathrm{~cm}$. Maximum effective wave height in the SoM is as much as $2.4 \pm 0.5$ and $3.3 \pm 0.7 \mathrm{~m}$ in fall and winter, respectively.

Wind stress on the water surface can result in a pushing or piling up of water in the downwind direction. During persistent southerly winds, mostly effective during winter, there may be a substantial rise in the sea level as high as $1 \mathrm{~m}$ along the northern shorelines of the SoM, called as surge caused by wind setup, wave setup, and air pressure drop (Alpar et al., 1999). During constant northerly winds, mostly effective during autumn and spring, there may be a substantial rise in the sea level about $1 \mathrm{~m}$ along the southern shorelines of the SoM.

Therefore it may be assumed that the sea level may be $1.25 \mathrm{~m}$ above the mean sea level. On the other hand, coseismic subsidence may be effective in some areas such as wetlands or marsh, as observed in case of 1999 event in İzmit Bay (Altınok et al., 2001b). Especially some alluvial flats along the SoM coasts may be opposed to coseismic subsidence which should be estimated from study of wetland soils buried during prehistoric subsidence events. Subsidence inferred from the prehistoric geologic record may increase in large estuaries. Therefore, an additional run-up $<1 \mathrm{~m}$ can be added for such potential localities. In fact, estimates of prehistoric tsunami run-up require extensive and expensive field studies. Tsunami run-up estimates are generally within the uncertainty of the run-up elevations estimated from the prehistoric data. Therefore such adjustments may make only minor differences in the mapped inundation, and in calculations, neither uplift nor subsidence was assumed.

\section{Conclusion and Suggestions}

Disasters such as the Tsunami create overwhelming and urgent demands for the population in the affected area, and it is obvious that they will present unique problems that complicate efforts to regulate intervention. In such environments as uncertainty, operational friction, time constraints, and the need for interagency coordination, disaster and crisis managers need to conduct experimental studies to meet complex demands that can be independent of each other.

Disasters create irresistible stresses to affected publics and pose unique unsolved problems that confuse efforts of orchestrating the response. They are multifaceted events that cannot be tolerably achieved merely by mobilizing more resources. Primary disaster research highlighted that disasters require administrations to develop new goals and objectives, to refine their internal structure, to organize and share resources with other organizations, and to establish new structures altogether (Auf der Heide 1989). Emergency planning endeavors to build an emergency response system before disaster strikes (Perry and Lindell, 2006; Karagiannis and Synolakis, 2017).

The speed of decision-making is critical, as the additional destruction caused by a tsunami that might develop after a sudden and destructive earthquake may expire until some decisions are made. Because today's operational environment is managed by multiple agencies, additional decision-making time should be taken into account in contingency operations plans. It should be known that well-organized relatively small and local organizational units can produce more effective solutions than crowded but unorganized structures, but it is possible to determine coordination and responsibilities before disasters.

Although there are many uncertainties in tsunami hazard assessment such as earthquake parameters, landslide geometry, bathymetry and topography data, numerical modeling, etc., evidence can be found in the projected geographical locations regarding the development of tsunami hazard on the SoM coasts. Until now, the tsunami on the shores of the Sea of Marmara has not been considered in the forefront as it usually develops after very destructive earthquakes, but after the earthquake in 1509, called the Little Apocalypse, 6 meters high waves that exceed the walls were mentioned and recorded in historical records. Latcharote et al. according to the numerical models developed by (2016), even in the case of the worst-case scenario, a tsunami wave reaching this height should not be expected. However, according to various reports and publications (IPTAP, 2019), there is a devastating tsunami danger, which should be expected to cause very serious losses on the shores of the SoM, which may develop completely unexpectedly after a great and devastating earthquake or with submarine landslide, or both situations, which we can call the worst case scenario, may develop together.

It is estimated that the tsunami wave will be effective in all districts located on the coast of the SoM and on the banks of streams and rivers that reach the SoM.

Some coastal morphological units and features (lagoons, lakes, river mount, fan shaped, flat units and seawards orientation of shoreline, slopes, walls, ridges) are under tsunamigenic risks in SoM. Tsunamis are unpredictable events and increasing the uncertainty of preventive action, contribute to a very low social memory on these phenomena that is inversely related with a high demand for decision criteria based on scientific knowledge. On the basis of this contextual situation which shows us the urgent necessity to develop integrated actions research, tsunami risk maps in a microzonation sense along the SoM coasts were produced. Inundation mapping efforts depend upon the numerical tsunami modes based on the landslide and slump hazards in the Sea of Marmara. Such kind of models developed for tsunami generation, propagation and coastal amplification are not enough to know the maximum run-up with any certainty. On the basis of new marine surveys, shallow water models should be developed and upgraded to a better convenient faster accurate level. Simulation of historical events is 
important. Comparisons between simulated results and other observations allow the first estimation of the source energy.

One should not forget that a local tsunami generally produces run-up significantly higher than that of a distant generated tsunami, provided that the source earthquakes were of similar magnitude. Therefore, the tsunami waves may be destructive along the SoM coasts of İstanbul and for shallower areas $<20 \mathrm{~m}$. The effect of tsunami can be minimized on flat coastal by planting tree belts between shorelines and areas needing protection.

Narrow estuaries and straits may maintain or amplify the wave height of open coastal tsunamis. The coastal runup is assumed to decrease inland in barrier-protected bays and estuaries. Experiments showed that a run-up is locally higher if the tsunami partially or completely overtops the barrier, strikes a shoreline directly behind the entrance to an estuary, or enters a constriction in the estuary. Such errors should be added to the average runup value to obtain the final run-up elevation.

In future, if any area is found to be underlain by deposits inferred to be from historic or prehistoric tsunamis, these areas should be included in the inundation boundaries we have defined. Since tsunamis can inundate without leaving behind a sediment deposit, presence of deposits was considered a good indication of minimum inundation. There will be waterways that carry the tsunami effects inland by natural or artificial channels that provide drainage of rainwater and surface waters into the sea. Because underwater structures that can be designed to prevent the entry of tsunami waves into these structures are quite costly, they must be built primarily in populated areas. In this regard, a broad perspective investment strategy is needed.

The potential for high seismic activity in the SoM, as well as the existence of active submarine landslides are considered accepted because the reality is that motion in the field of printing by the tsunami, considering all the circumstances, Provincial, District and region-based high-resolution damage vulnerability values produced should be of the order of disaster preparedness tsunami hazard maps should be produced for each region and the spatial distribution to be calculated, the results should be marked on the land in a way that everyone can understand. Tsunamis have a strong drag force due to the high flow rate they have, but the materials carried significantly increase the destructive power of the tsunami wave. In order to reduce this risk, environmental regulations should be made for all kinds of drag materials that may increase damage, taking into account structure and human density.

Transport axis strategies developed parallel to the coastal line produce smooth and unobstructed surfaces by disrupting the natural characteristics of the coast and causing greenery to decrease, thus making it easier for tsunami waves to reach the land quickly and over great distances. As the afforestation works along the coast will play a great effect in reducing the loss of property and life besides the tsunami energy, it is expected that the trees in the potential dominant regions will create a tsunami barrier and partially prevent the wave energy, thus preventing the debris drift and reducing the loss of life.

as suggested in his various studies,

As with all natural disasters, all the measures to be taken in the face of a natural disaster such as Tsunami should be provided in coordination with the both central and local administration. The focal point of the measures to be taken at the local level should be put into practice according to the requirements and features of local conditions and geomorphology/geology. As suggested in their several studies (Kaya et al., 2008a,b), the central administration should have generic characteristics for the disasters to be received, as well as for the development of people's disaster culture, and at the local level, it should be aimed at realizing investment-oriented activities that cannot be realized by local government mechanisms.

All established facilities along the coast, ports, shelters, marinas, boarding points and etc. should be considered areas at risk and an action and Prevention Plan should be developed for the related facilities. The awareness that the vast majority of these facilities are an element of the evacuation and relief mechanism after a possible devastating earthquake should be reviewed by the authorities and the tsunami risks should be examined and classified and examined. As a manifestation of a safety culture, the operation of the evacuation mechanism after a devastating earthquake is important. Subject to consideration of the impact of a successful evacuation for the tsunami wave and take the necessary measures to build levees to prevent disassembly of the tsunami waves into the land after a devastating earthquake and tsunami with the wrong routes, blocking the fatal secondary induced fatalities will reduce.

\section{References}

Abal1, H. (2005). Assessment of tsunami hazard in the Marmara Sea. MsC thesis (unpublished), 96p.

Aksu, A.E.;Calon, T.J., Hiscott, R.N. (2000). Anatomy of the North Anatolian Fault Zone in the Marmara Sea, western Turkey: extensional basins above a continental transform, GSA Today, 10 (6), June 2000, 3-7.

Alpar, B., Altınok, Y., Gazioğlu, C. Yücel, Z.Y. (2002). Tsunami Hazard Assessment in İstanbul Turkish Journal of Marine Sciences 9 (1):3-29.

Alpar, B., Gazioğlu, C., Altınok, Y Yücel, Z.Y. Dengiz, Ş. (2004). Tsunami hazard assessment in Istanbul using by high resolution satellite data (Ikonos) and DTM, XXth Congress of the ISPRS, Istanbul.

Alpar, B., Yalçıner, A.C., Imamura, F., Synolakis, C.E. (2001). Determination of probable underwater failures and modeling of tsunami propagation in the Sea of Marmara. Proceedings of the International Tsunami Symposium 2001, August 7-10, 2001, Seattle, Washington, USA, pp. 535-544.

Altınok, Y., Alpar, B., Yaltırak, C. (2003). ŞarköyMürefte 1912 Earthquake's Tsunami, Extension of the Associated Faulting in the Marmara Sea, Turkey. Journal of Seismology, 7(3): 329-346. 
Altınok, Y., Alpar, B.Ş., Özer, N. Aykurt, H. (2011). Revision of the Tsunami Catalogue affecting Turkish coasts and surrounding regions Natural Hazards And Earth System Sciences, 11: 273-291.

Altınok, Y., Alpar, B.Ş., Özer, N. Gazioğlu, C. (2005). 1881 and 1949 earthquakes at the Chios-Cesme Strait (Aegean Sea) and their relation to tsunamis. Natural Hazards And Earth System Sciences, 5(5): 717-725.

Altınok, Y., Ersoy, Ş., Yalçıner, A.C., Alpar, B., Kuran, U. (2001a). Historical tsunamis in the Sea of Marmara, International Tsunami Symposium 2001 Proceedings, NOAA, Pacific Marine Environmental Lab., Editor(s) : Eddie Bernard and Frank Gonzales,: U.S.A., Session 4, Number 4-2: 527 - 534.

Altınok, Y., Tinti, S., Alpar, B., Yalçıner, A.C., Ersoy, Ş., Bortolucci, E. Armigliato, A., (2001b). The tsunami of August 17, 1999 in İzmit Bay. Natural Hazards, 24: 133-146.

Ambraseys, N.N. (1960). The seismic sea wave on July 9, 1956, in the Greek Archipelago. J. Geoph. Res. 65: 1257-1265.

Ambraseys, N.N. (1962). Data for the investigation of the seismic sea-waves in the Eastern Mediterranean. Bull. Seism. Soc. Am. 52: 895-913.

Ambraseys, N.N. Finkel, C.F. (1991). Long term seismicity of İstanbul and of the Marmara Sea region. Terra Nova, 3, 527-539.

Ambraseys, N.N. Finkel, C.F. (1995). The Seismicity of Turkey and Adjacent Areas. A Historical Review, 1500-1800. Eren Yayınc1lik, İstanbul.

Ambraseys, N.N., Jackson, J.A. (2000). Seismicity of the Sea of Marmara (Turkey) since 1500. Geophys. J. Int. 141, F1- F6.

Antonopoulos, A. (1978). Contribution to the knowledge of tsunamis in the Eastern Mediterranean from ancient times until the recent. Ann. Geol. Des. Pays. Helleniques, Le serie TXXIX/2: 740-757.

Armijo, R.; Meyer, B.; Hubert, A., Barka, A., (1999). Westward propagation of the North Anatolian Fault into the northern Aegean: timing and kinematics. Geology, 27, 267-270.

Auf der Heide, Eric. (1989). Disaster Response: Principles of Preparation and Coordination. St. Louis, MO: Mosby

Barka, A.A. (1996). Slip distribution along the North Anatolian Fault associated with the large Earthquakes of the period 1939 to 1967 . Bull. Seismol. Soc. Am. 86, 1238- 1254.

Barka, A.A., Kadinsky-Cade, K., (1988). Strike-slip fault geometry in Turkey and its influence on earthquake activity. Tectonics, 7, 663-684.

Batur, A. (1994). Bir depremin yüzyıl dönümü. İstanbul Dergisi 10: 24-33.

Batur, A. (1999). Muharrem ayında bir salı günü. Cogito, Deprem Özel Sayısı, Yapı ve Kredi Yayınları, İstanbul, 20: 42-59,.

Çesmi-zade, M.R. (1766-1768). Cesmizade Tarihi (1766). Ed. B.S. Kütükoglu, Istanbul Fetih Cemiyeti Yayınlar1 1993.

Crampin, S. Evans, R. (1986). Neotectonics of the Marmara Sea region of Turkey, Journal Geological Society, 143, 343-348.
Eginitis, D. (1894). "1310 Zelzelesi Hakkında Rapor", Translated by Bogos, İstanbul, 21 Agustos 1310 Başbakanlık Arşivi Genel Müdürlüğü, Yıldız Esas Evrakı Sıra No. 674, Dosya No. 11, Gömlek No. 24, Varak 29 (hadwritten manuscript, 1894).

Gazioğlu, C. (2017). Assessment of Tsunami-related Geohazard Assessment for Coasts of Hersek Peninsula and Gulf of İzmit, International Journal of Environment and Geoinformatics, 4(2), 63-78. doi. 10.30897/ijegeo.312554

Gazioğlu, C., Alpar, B., Yücel, Z. Y., Müftüoğlu, A. E., Güneysu, C., Ertek, T. A., Demir, V., Kaya, H. (2014). Morphologic features of Kapıdağ Peninsula and its coasts (NW-Turkey) using by remote sensing and DTM. International Journal of Environment and Geoinformatics, 1(1), 48- 63.

Gazioğlu, C., Gökaşan, E., Algan, O. Yücel, Z. Y., Tok, B., Doğan, E., (2002). Morphologic features of the Marmara Sea from multi-beam data, Mar. Geol., 190(1-2): 397-420.

Gazioğlu, C., Yücel, Z.Y., Dogan, E. (2005). "Morphological features of major submarine landslides of Marmara Sea by using multi beam data". Journal of Coastal Research, 21(4), 664-673.

Gazioğlu, C.; Gökaşan, E.; Algan, O.; Yücel, Z.Y.; Tok, B., Doğan, E. (2002). Morphologic features of the Marmara Sea from multi-beam data. Marine Geology, 190, 397-420.

Gökaşan, E. Gazioğlu, C., Alpar, B.; Yücel, Z.Y.; Ersoy, Ş. Gündoğdu, O., Yaltirak, C. (2002). Evidences of NW extension of the North Anatolian Fault Zone in Marmara Sea; a new approach to the 17th August 1999 Marmara Sea earthquake. Geo-Marine Letters, 21(4): 183-199.

Gökașan, E.; Alpar, B.; Gazioğlu, C.; Yücel, Z.Y.; Tok, B.; Doğan, E., Güneysu, C. (2001). Active tectonics of the I'zmit Gulf (NE Marmara Sea): from high resolution seismic and multibeam bathymetry data. Marine Geology, 175/1-4, 271-294.

Gökaşan, E.; Ustaömer, T.; Gazioğlu, C.; Yücel, Z.Y.; Öztürk, K.; Tur, H.; Ecevitağlu, B., Tok, B. (2003). Morpho-tectonic evolution of the Marmara Sea inferred from multi-beam bathymetric and seismic data. Geo-Marine Letters, 23(1), 19-33.

Grilli S.T. Watts, P. (1999). Modeling of waves generated by a moving submerged body; applications to underwater landslides. Engineering Analysis with Boundary Elements 23: 645-656.

Guidoboni, E., Comastri, A. Traina, G. (1994). Catalogue of Ancient Earthquakes in the Mediterranean Area up to 10th Century, Instituto Nazionale di Geofisica, Rome.

Hayir, A., Seseoğullari, B., Kilinç, İ., Ertürk, A., Çigizoğlu, H.K., Kapdaşli, M.S., Yağci, O. Day, K. (2008). Scenarios of tsunami amplitudes in the North eastren coast of Sea of Marmara generated by submarine mass failnure. Coastal Engineering, 55, 333-356.

Hébert, H., Schindele, F., Altinok, Y., Alpar, B., \& Gazioglu, C. (2005). Tsunami hazard in the Marmara Sea (Turkey): a numerical approach to discuss active faulting and impact on the Istanbul coastal areas. Marine Geology, 215(1-2), 23-43. 
Heck, N.H. (1947). List of seismic sea waves. Bull. Seism. Soc. Am. 37: 269-286.

Hills, S.G. Mader, C.L. (1997). Tsunami produced by the impacts of small asteroids, Annals of the Sciences, 822: 381-394.

Imamura, F. Imteaz, M.A. (1995). Long waves in two layer, governing equations and numerical model. Journal of Science of Tsunami Hazards, 13(1): 3-24.

Imamura, F., Koshimura, S. Yalçıner, A.C. (1999). Field survey and numerical modeling of tsunami generated by Turkish Earthquake of August 17, 1999. Proceedings of Coastal Engineering in Japan 47: 331-335 (in Japanese).

Imren, A.; Le Pichon, X.; Rangin, C.; Demirbağ, E.; Ecevitoğlu, B., Görür, N. (2001). The North Anatolian Fault within the Sea of Marmara: a new evaluation based on multichannel seismic and multibeam data. Earth Planetary Science Letters, 186, $143-158$.

IPTAP (2019). Istanbul Province Tsunami Action Plan, Istanbul greater Municipality and METU Report, $334 \mathrm{p}$.

Karagiannis, GM., Synolakis, C. (2017). Twenty challenges in incident planning, Journal of homeland security and emergency management, 14(2), 1-12.

Kastens, K., Kekelidze, G., King, R., Kotzev, V., Lenk, O., Mahmoud, S., Mishin, A., Nadariya, M., Ouzounis, A., Paradissis, D., Peter, Y., Prilepin, M., Reilinger, R., Sanli, I., Seeger, H., Tealeb, A., Toksfz, M.N., Veis, G. (2000). Global Positioning System constraints on plate kinematics and dynamics in the eastern Mediterranean and Caucasus. $J$. Geophys. Res. 105, 5695- 5719.

Kaya, H., Orakçı, V., Yücel, ZY., Gazioğlu,C. (2008a). Yerel Yönetim Perspektifinde Afet Yönetimi, Kent Yönetimi, Insan ve Çevre Sorunlarl 08 SempozyumuUlusal Jeomorfoloji Sempozyumu, 371379.

Kaya, H., Orakçı, V., Yücel, ZY., Gazioğlu,C. (2008b). Yerel Yönetimlerde Afet Risk Yönetimi, Ulusal Jeomorfoloji Sempozyumu, 294-301.

Ketin, I* (1968). Relations between general tectonic features and the main earthquake regions in Turkey. MTA Bulletin, 71, 129-134.

Kılınç, I., Hayır, A. Çigizoğlu, H.K. (2009) Wave dispersion study for tsunami propagation in the Sea of Marmara. Costal engineering, 56, 982-991.

Kumar, C. S., Murugan, P. A., Krishnamurthy, R. R., Batvari, B. P. D., Ramanamurthy, M. V., Usha, T. Pari, Y. (2004). Inundation mapping - a study based on December 2004 Tsunami Hazard along Chennai coast, Southeast India, Natural Hazards and Earth System Sciences, :8 (4), 617-626.

Latcharote, P., Suppasri, A., Imamura, F., Aytore, B. Yalciner, AC. (2016). Possible worst-case tsunami scenarios around the Marmara Sea from combined earthquake and landslide sources, Pure Appl. Geophys. $173 \quad$ (2016), 3823-3846, doi.10.1007/s00024-016-1411-z.

Le Pichon, X.; Sengör., A.M.C.; Demirbağ., E.; Rangin, C.; İmren, C.; Armijo, R.; Görür, N.; Cağatay., N.; Mercier De Lepinary, B.; Mayer, B.; Saatçiler., R.,
Tok, B. (2001). The active main Marmara Fault. Earth and Planetary Science Letters, 192, 595-616.

McClusky, S., Balassanian, S., Barka, A., Demir, C., Ergintav, S., Georgiev, I., Gurkan, O., Hamburger, M., Hurst, K., Kahle, H., et al. (2000). Global Positioning System constraints on plate kinematics and dynamics in the eastern Mediterranean and Caucasus, Journal of Geophysical Research Atmospheres, 105(B3):5695-5719

Mihailovic, J. (1927). Memoir-Sur les Grands Tremlement de Terre de la Mer de Marmara, Beograd, 215-222.

Nanadasena, N.A.K., Tanaka, N. Tanimoto, K. (2008), Tsunami current innudation of Ground with voastal vegetation effects: An initial step towards a natural solution for tsunami amelioration. J. of Earthquake and Tsunami,.2(2): 157-171.

Okay, A. I.; Kaşlılar, Özcan, A.; İmren, C.; BoztepeGüney, A.; Demirbağ , E., Kuşcu, İ. (2000). Active faults and evolving stike-slip basins in the Marmara Sea, northwest Turkey: a multichannel seismic reflection study. Tectonophysics, 321, 189-218.

Okay, A.; Demirbağ, E.; Kurt, H.; Okay, N., Kuşçu, İ. (1999). An active, deep marine strike-slip basin along the North Anatolian fault in Turkey. Tectonics, 18(1), 129-147.

Örgülü, G. Aktar, M. (2001). Regional moment tensor inversion for strong aftershocks of the August 17, 1999, İzmit Earthquake $(\mathrm{Mw}=7.4)$, Geophys. Res. Lett., 28(2):, 371-374.

Orgun, Z. (1941). 1509 (Hicri 915) senesinde İstanbul'u baştan başa harap eden zelzele ve şehri tamir için alınan tedbirler. Arkitekt Neşriyatı, İstanbul.

Özbay I. (2000). Two Layer Model for Tsunami Generation, M.Sc. Thesis, Middle East Technical University, Civil Engineering Department, Ocean Engineering Research Center.

Öztin, F. Bayülke, N. (1991). Historical earthquakes of İstanbul, Kayseri, Elazığ. Proceedings of the Workshop on Historical Seismicity and Seismotectonics of the Mediterranean Region, 10-12 Oct. 1990, Turkish Atomic Energy Authority, Ankara, 150-173.

Papadopoulos, G.A. (2000). Tsunamis in the East Mediterranean: a catalogue for the area of Greece and adjacent seas, In : Tsunami Risk Assessment Beyond 2000: Theory, Practice and Plans, Tsunami Risk Workshop, Moscow, Russia, June 2000, Proceedings, V.K. Gusiakov, B.W. Levin, O.I. Yakovenko (eds.), 34-43.

Papadopoulos, G.A., Chalkis, B.J. (1984). Tsunamis observed in Greece and the surrounding area from antiquity to the present times. Mar. Geol. 56: 309317.

Papazachos, B.C., Koutitas, Ch., Hatzidimitriou, P.M., Karacostas, B.G. Papaioannou, Ch.A. (1986). Tsunami hazard in Greece and the surrounding area. Annales Geophysicae 4B,1: 79-90.

Parke, J.R.; Minshull, T.A.; Anderson, G.; White, R.S.; Mckenzie, D.; Kuşçu, İ. Bull, M.J.; Görür, N., Şengör, C. (1999). Active faults in the Sea of Marmara, western Turkey, imaged by seismic reflection profiles. Terra Nova, 11(5), 223-227. 
Perry, Ronald W., Michael K. Lindell. (2006). Emergency Planning. New York: Wiley.

Pinar, N. (1942). Geologique et meteorologique sismiques du bassin de la mer de Marmara, I.U. Fen Fak. Mecm., Series A, Cilt VII(3/4), 121, 182.

Priest, GR. (1995). Explanation of Mapping Methods and Use of the Tsunami Hazard Maps of the Oregon Coast, State of Oregon Department of Geology and Mineral Industries, Suite 965, 800 NE Oregon St., \#28 Portland, Oregon 97232, Open-File Report O95-67.

Reilinger, RE., Ergintav, S., Bqrgman, R., McClusky, S., Lenk, O., Barka, A., Gurkan, O., Hearn, L., Feigl, K.L., Cakmak, R., Aktug, B., Özener, H., Toksoz, MN. (2000). Coseismic and postseismic fault slip for the 17 August 1999, M=7.5, Izmit, Turkey earthquake. Science 289, 1519-1524.

Sadi (1912). Marmara Havzasının 26-27 Temmuz Hareket-i Arzi 15 Eylül 1328, Istanbul, Resimli Kitap Matbaas1, 45p (Ottoman Language).

Selimoğlu, Z. (1999). Deprem, bir yaratık olarak. Pen'in Deprem Kitabı, Ay Sallanıyor, Cumhuriyet Kitap Klübü, Istanbul, 296-300.

Şengor, A.M.C. (1979). The North Anatolian Transform Fault; its age offset and tectonic significance. Journal Geological Society, London, 136, 269-282.

Siyako, M.; Tanis, , T., and Sarığlu, R., 2000. Marmara Denizi'nin aktif fay geometrisi (active fault geometry of the Marmara Sea). Bilim ve Teknik, 388, 66-71.

Soysal, H. (1985). Tsunami (deniz taşması) ve Türkiye kıyılarını etkileyen tsunamiler, İstanbul University, Bulletin of Marine Sciences and Geography, 2: 5967.

Soysal, H., Sipahioğlu, S., Kolçak, D. Altınok, Y. (1981). Türkiye ve Çevresinin Tarihsel Deprem Kataloğu (MO 2100-MS 1900), TUBITAK project Tbag 341, İstanbul.

Stein, R.S., Barka, A.A, Dieterich, J.H., 1997. Progressive failure on the North Anatolian Fault since 1939 by earthquake stress triggering. Geophys. J. Int. 128, 594- 604 .

Straub, C. (1996). Recent crustal deformation and strain accumulation in the Marmara Sea region, NW Anatolia, inferred from GPS measurements, $\mathrm{PhD}$. Thesis, Institut für Geodesie und Photogrammetrie, Mitteilungen Nr. 58, Zürich.

Synolakis, C.E., Bardet, J.P., Borrero, J., Davies, H., Okal, E., Silver, E., Sweet, S. Tappin D. (2002). Slump origin of the 1998 Papua New Guinea Tsunami. Proceedings of the Royal Society, Series A.

Synolakis, C.E., Borrero, J., Yalçıner, A.C. (2001). Developing inundation maps for the state of California. In : A.C., Yalçıner, (Ed.), NATO Advanced Research Workshop, Underwater Ground Failures on Tsunami Generation, Modeling, Risk and Mitigation, Book of Abstracts, May 23-26, 2001, Istanbul, 188-192.

Yalçıner, A.C., Alpar, B., Altınok, Y., Özbay, İ., Imamura, F. (2002). Tsunamis in the Sea of Marmara: Historical documents for the past, models for the future, Marine Geology, 190(1-2): 445-463.

Yalçıner, A.C., Alpar, B., Özbay, İ:, Altınok, Y. Imamura, F., (2001b). Tsunami generation and coastal amplification in the Sea of Marmara, NATO Advanced Research Workshop, Underwater Ground Failures On Tsunami Generation, Modeling, Risk and Mitigation, Book of Abstracts, 23-26 May1s 2001, Istanbul, 138-146.

Yalçıner, A.C., Synolakis, C.E., Alpar, B., Borrero, J., Altınok, Y., Imamura, F., Tinti, S., Ersoy, Ş., Kuran, U., Pamukçu, S., Kanoğlu, U. (2001a). Field surveys and modeling of the 1999 İzmit Tsunami. Proceedings of the International Tsunami Symposium 2001, August 7-10, 2001, Seattle, Washington, USA, 557-564.

Yalçiner, A.C.; Alpar, B.; Altınok, Y.; Özbay, İ., Imamura, F. (2002). Tsunamis in the Sea of Marmara. Historical documents for the past, models for the future. Marine Geology, 190, 445-463.

Yaltırak, C. (2002). Tectonic evolution of the Marmara Sea and its surroundings, Marine Geology, 190(1-2): 493-529.

Yılmaz, Y., Gökaşan E. Erbay, Y. (2009). Morphotectonic development of the Marmara Region. Tectonophysics, doi: 10.1016/j.tecto.2009.05.012. 